\title{
Installment Financial Sharing (IFS): A Financial Subsystem of Rastin PLS Banking
}

\author{
Bijan Bidabad \\ B.A., M.Sc., Ph.D., Post-Doc. \\ Professor \\ Economics and Chief Islamic Banking Advisor \\ Bank Melli, Iran \\ E-mail:bijan@bidabad.com
}

\begin{abstract}
Installment Financial Sharing (IFS) is a subsystem of Rastin Profit and Loss Sharing (PLS) Banking System, and the guidelines, instructions, organization, workflow and electronic mechanism of Rastin PLS Banking have been put forward for this subsystem as well. Profit in this financial sharing method is based upon the yield of the real sector, and bank as an intermediary of funds, receives a commission as like as an agent, and provides capital management and financial services to financer (depositor) and participates in investment project of the entrepreneur on behalf of the depositor. In installment Financial Sharing, the contribution of the depositor is paid back by installments and ownership of the project is finally transferred to entrepreneur.Financial innovations of "Mughasatah Certificate" and "Musharakah Mughasatah Certificate" and "Rental Mughasatah Certificate" are used in this subsystem. The financer (depositor) of sharing project receives a certificate, which is negotiable in Rastin Certificate Market via the internet.
\end{abstract}

Keywords: Mughasatah, Installment, Sharing, Rastin PLS Banking, Islamic banking, Usury-free banking

\section{Introduction and Objective}

Rastin PLS banking was designed to implement usury-free Islamic banking. The base system of this type of banking actually provides the necessary structure and organization for financial participation. But it was necessary to paste some new financial subsystems to the base system to satisfy the needs of the banking clients. Installment Financial Sharing (IFS) was designed to fulfill Rastin PLS Banking System to complete some of its shortcomings. IFS ${ }^{1}$ provides the background for depositor participation in the investment project in which entrepreneur desires to preserve his own ownership, and depositor wishes to obtain periodic income (monthly, seasonal, or yearly). IFS is a subsystem of Rastin PLS Banking System, its guidelines, instructions, organization, workflow, electronic mechanism and contracts are highly similar to Rastin PLS Banking, and the latter characteristics have been described in detailed PLS banking documents. ${ }^{2}$

In IFS, the bank is a firm that works on behalf of the depositor, and allocates his deposit to entrepreneur and divides the profit or loss of the entrepreneur's investment between the depositor and the entrepreneur according to the signed contract and receives a commission for providing financial management services.

\section{Installment Financial Sharing (IFS)}

In this subsystem, the interest rate of installments and rents are in accordance with investment real return, and the bank is intermediary of funds, and receives a commission as an attorney or agent and provides financial and capital management services for his clients. In IFS, the return of principal capital and yield of conducting activities are paid to depositors periodically, and the ownership of the investment project will be transferred to the entrepreneur after the payment of the last installment. Accordingly, bank allocates the capital (deposit) of the depositor in IFS projects based on the will of the depositor and finally divide the profit among depositor and entrepreneur and pay back the

\footnotetext{
1 - Bidabad, Bijan. Installment Financial Sharing (IFS), a subsystem of Rastin PLS banking, Planning and Research Department of Bank Melli Iran, Tehran, 2011. http://www.bidabad.com/doc/detailed-ifs.pdf

2 - The Persian and English documents of Rastin Banking including detailed explanation of this banking method can be accessed through http://www.bidabad.com in full texts.
} 
principal and profit of investment to the depositor by installment and transfer the ownership of the project to entrepreneur. Profit and loss will be divided between them according to their agreement in the contract based on the Rastin PLS banking instructions, after deduction of bank commission.

Bank deals with depositor through Joalah contract and goes through three new contracts of "Mughasatah", "Rental Mughasatah" and "Musharakah Mughasatah" with entrepreneur and according to depositor desire, will provide the conditions for his financial participation within the entrepreneur's project.

An entrepreneur is a legal or real entity who receives deposited funds of depositor via the bank and according to the agreement will invest in the pre-agreed project. Depositor provides part of the fund for the entrepreneur's project, and entrepreneur provides the bank with appropriate guarantees to cover the fulfillment of his obligations. "Trustee" is a unit that supervises the process of IFS on behalf of the bank in order to make sure about the goodness of fulfillment of the project operations.

There are several financial innovations in IFS such as "Mughasatah Certificate", "Rental Mughasatah Certificate", and "Musharakah Mughasatah Certificate", which provide new preparations for investment projects. These certificates are digitally negotiable on the internet in Rastin Certificate Market (RCM) ${ }^{3}$ of the bank. The certificate holder (depositor) can transact his certificate over the internet; hence, they are negotiable at the international level.

By applying to Rastin PLS bank branch, the entrepreneur proposes an IFS project proposal to the bank. In addition to informing the entrepreneur about the conditions and regulations concerning IFS (according to written instructions), the necessary documents, information, and analysis about the project, including economic, technical and financial justification and other related information of the project will be received from the entrepreneur. According to available previous records of entrepreneur activities, the assessment unit will assess the entrepreneur's capability and ability according to written instructions and will report to the PLS department. If the assessment is positive, according to the related instructions, the quality and quantity of needed collaterals or guarantees will be defined, and after signing a contract, the needed funds will be paid to entrepreneur. All documents including the detail of sharing subject, budgeting, time schedule, funds and the way of fund consuming, implementation of the project and its phases, quality control method, reporting and fulfillment of the project and its installments will be provided by the entrepreneur to the bank assessment unit. Reports provided by the bank trustee unit will be the basis for all entrepreneur activities evaluations.

By applying to information portal (website) of Rastin Certificate Market (RCM), depositor becomes familiar with the rules and conditions and selects his desired entrepreneur's investment proposal. By signing and registering the contract, and after the payment, the system automatically issues the certificate. After each financial period and at the end of the contract, under the supervision of the bank's trustee, entrepreneur calculates the share of principal and profit of the project and passes it to depositor via bank.

According to the written instructions and related formulas, the amount of installments, rent or periodic yield and commission share of the bank will be calculated by the accounting/auditing unit. The share of entrepreneur and depositor will be defined by considering the kind of IFS financing and the method of installment payment and rent (profit or loss). In the case of discontinuance of the project, the occurred losses will be calculated according to the compiled instructions. The structure and organization of Rastin PLS banking are also applied to the subsystem of IFS.

\section{Mughasatah Contracts}

In order to perform IFS operations, a new contract by the title "Mughasatah" is defined:

\section{Mughasatah}

"Mughasatah" is defined as a contract in which the moghsit (depositor) will provide a part or total amount of funds and by providing the remainder, ghasit (entrepreneur) will invest and pay back the borrowed amount to moghsit

3 - Bidabad, Bijan, Safaeipour, Mohammad, The Electronic Market for Transaction of Musharakah (Partnership)/Pazireh (Subscripted) Certificates. Fifth Conference of E-Commerece, 23-24, November 2008, Ministry of Commerce, Tehran, Iran. http://www.bidabad.com/doc/charchoobe-bazare-electronic-pls.pdf 
(depositor) in periodic installments and finally becomes the owner of the project. This procedure uses "Mughasatah Certificate" as its financial instrument. This contract is used for those projects that can be finished after a period. Moghsit (depositor) has the right to receive the installments until he is paid off, and the entrepreneur becomes the owner of the project. If the project is to be concluded to receive rent at compromising contract time, the procedure in these types of projects works by issuing "Rental Mughasatah Certificate".

\section{Rental Mughasatah}

For finitude projects, "Rental Mughasatah", the entrepreneur can be a real person or legal entity. Moghsit (depositor) has the right to receive installments plus the rent until the end of the project, and the entrepreneur will own total project after then. The rent will be defined in the contract to be paid by installment, or calculated as a share of the finished project as assessed at the beginning of the contract. It is not necessary to pre-fix the amount of rent for all periods, but this must be cited in the contract. "Rental Mughasatah" is a kind of contract in which moghsit (depositor) provides a part or total fund for project and ghasit (entrepreneur) will finance the remainder and invest the funds in the moghsatah (project) and pays rent to the moghsit (depositor). Then, the share of the depositor from the assessed (valuated) value of the constructed project is calculated according to the amount of his fund and the period of his participation and will be paid by installment to the depositor in addition to rent payment. In the end, the ownership of the project will be transferred to the entrepreneur. The amount of periodic rent might be different according to the signed contract.

\section{Musharakah Mughasatah}

The entrepreneur of prolong (endless) projects should be a legal entity. In this case, also the depositor has the right to receive back his own share, plus a share of the yields of the project until the contract terminates. Then, the entrepreneur will become the owner of the constructed project. In this case, bank issues "Musharakah Mughasatah Certificate". "Musharakah Mughasatah" is a contract, in which depositor provides a part or total amount of resources needed for project financing and entrepreneur provides the remainder, then, the share of the depositor from the valuated (assessed) of constructed project and its yields (productivity) is calculated according to the amount of his share and the period of his participation and will be paid by installment to depositor.

\section{Mughasatah Certificate}

"Mughasatah Certificate" is an anonym document issued by Rastin PLS bank with a nominal price for real financial participation (sharing) for a certain period. The bearer of this paper receives periodic payments relative to his share and the period of participation. Payments will be paid at the end of each period. In the end, the entrepreneur will own the project.

\section{Rental Mughasatah Certificate}

"Rental Mughasatah Certificate" is an anonym document with the defined nominal price for a defined period of time (rental tenure) issued by Rastin PLS bank which conducts Rastin PLS activity. The owners of these certificates have right on the results of the sharing project which is proportional to the nominal value of the certificate and the duration of holding certificate until the end and receive periodic rent and installment of the valuation of the project at the end of each period. At the end of the contract, the entrepreneur will become the owner of the project.

\section{Musharakah Mughasatah Certificate}

"Musharakah Mughasatah Certificate" is an anonym document with a defined nominal price for a defined period of time (Musharakah tenure) issued by Rastin PLS bank which conducts PLS activities. The owner of this certificate has right on the result of the sharing project proportional to the nominal value of the certificate and the duration of holding the certificate until the end of the contract, and receive periodic installment plus income (positive/negative) yields of the project at the end of each period. In the end, the entrepreneur will become the owner of the project.

All Mughasatah certificates are kinds of Rastin Certificates ${ }^{4}$ and obtain rent, or yield plus installment until the end of the contract, and after the settlement of the contract, the entrepreneur becomes the owner of the project. The settlement of the project differs from finitude and endless (productive) projects. The settlement is after the payout of the last installment for "Mughasatah Certificate". In "Rental Mughasatah Certificate", after the payment of last installment and rent, the contract is settled. In "Musharakah Mughasatah Certificate", when the last payment of installments and profit or loss (yield) is paid, the settlement takes place.

\footnotetext{
${ }^{4}$ - Rastin certificates are the name for collection of certificates designed for Rastin PLS banking and operate under the supervision of trustee unit of bank and are issued with prefix of certificate.
} 


\section{The Amortisation Date of the Share of Moghsit (Depositor)}

This is the time when depositor has received all installments (including principal, rent, or the yield of investment) from the ghasit (entrepreneur) and had no more share in the project that belongs to the entrepreneur thereafter. This calculating is in connection with the duration of project after its construction period and the share of each party (regarding the tenure of their participation), the amount of share of depositors, the paid-in capital of entrepreneur, and the value added of the project (and dismantled value of the project at the end of its useful life - if applicable). Amortization date calculations of all Mughasatah contracts are similar. However, this point of time can be agreed upon by the bank on behalf of depositor and entrepreneur when the contract is signed.

\section{Dividing the Value of Project at the End of Construction Period}

Allotment of profit of the project between moghsits (depositors) and ghasit (entrepreneur) is one of the important issues of Mughasatah. Traditionally, this type of apportionment bases on mutual agreement, but in Installment Financial Sharing (IFS) this apportionment cannot be left to the bank; therefore, it was necessary to compile necessary rules for carrying it out accordingly. But, when installment enters the process of apportionment, conventionally it involves interest rate, which is not acceptable because of Reba. Hence, we should find a rational usury-free solution for it. Here we should answer two questions: first, how much are the values of work and capital in this project? Second, what rate of yield should be applied for the installment of the share of the depositor to be non-usury?

Before entering this discussion, we should pay attention that Mughasatah activity is economically a production process that creates value-added and therefore, we can answer the above questions from this viewpoint. In simple words, according to Neoclassical theory ${ }^{5}$, a firm is a unit in which products are produced by using factors of production (labor and capital). Mathematically, the production function of the firm is a relation of the labor and capital in the process of production. Now consider the process of a Mughasatah in which ghasit uses the factors of production of depositor as capital (K) and contributed capital of the entrepreneur (B) from one hand, and his factor of production (entrepreneur's labor work $(\mathrm{L})$ ) for the production of the project. The value of production function $(\mathrm{Q})$ mathematically is a function of factors of production and can be described as follows:

$Q=f(K+B, L)$

The above function does not have a fixed production factor, and the amount of production is defined by variable factors of production (labor and capital). The production structure is defined in such a period that investment does not change, and fixed cost does not enter the calculations. The applied technology, the know-how of entrepreneur in applying capital and labor in Mughasatah is defined as in the above function. Usually, the production function is defined as a single-valued continuous increasing function for non-negative values within the regarded domain and is usually regularly strictly quasi-concave. The contribution of depositor and entrepreneur are defined within a period. In this period, factors and the defined amount of production have three constraints: First, it should be short enough so that the ghasit cannot change the production factors. Second, it should be short enough that the production function cannot be changed due to the improvement of technology. Third, it should be long enough to cover all the process of Mughasatah. The marginal productivity of capital (K of moghsit plus B of ghasit) and ghasit's labor work $(\mathrm{L})$ are noted as $\mathrm{MP}_{\mathrm{K}+\mathrm{B}}$ and $\mathrm{MP}_{\mathrm{L}}$, and can be defined as follows:

$$
\begin{aligned}
& M P_{K+B}=\frac{\partial Q}{\partial(K+B)}=f_{K+B}(K+B, L)=f_{K+B} \\
& M P_{L}=\frac{\partial Q}{\partial L}=f_{L}(K+B, L)=f_{L}
\end{aligned}
$$

The law of marginal decreasing return explains that by increasing one factor of production, marginal production increases at first, but after a while, marginal production starts to decrease. That is to say, the more we use one of the

\footnotetext{
5 - For more information, see microeconomic texts, as: Henderson, R., Quandt, P. (1982), Microeconomic theory, a mathematical approach. Mc-Graw Hill.
} 
production factors, after a while, the less will be marginal production ${ }^{6}$. This law has distinct effects on the apportionment of the yields of Mughasatah that can be understood from dividing profit relationship that we will explain.

Economies of scale show the way of increasing production through the proportional increase of all factors of production. If Mughasatah value increases proportional to the increase of labor and capital (deposit plus contributed capital of the entrepreneur), the return to scale in the domain of the related factors of production is constant. The return to scale is positive if the proportional increase of labor, capital would increase the production more, and it is negative if the proportional increase of labor, capital results in less increase in production. Return to scale is defined by the concept of homogeneity of the production function. A production function is homogeneous of degree $\mathrm{j}$ if:

$$
f(t(K+B), t L)=t^{j} \cdot f(K+B, L)
$$

In which by an increase of $t$ times of labor and capital (sum of deposits and paid in capital) for amounts of $0<j<1$, $\mathrm{j}=1, \mathrm{j}>1$, the return to scale will be $\left(\mathrm{t}^{\mathrm{j}}\right)$ increasing, constant and decreasing respectively. A linear production function can result from several linear production activities simultaneously ${ }^{7}$. Linear production functions are homogeneous of degree one and therefore, have a constant return to scale. Homogeneity in production function means that if we increase/decrease all factors of production proportionally, production will also increase/decrease proportionally. If production increases/decreases proportionally as an increase/decrease of factors of production, the production function is homogeneous of degree one. If the ratio of the production increase is less than the increase in factors of production, homogeneity has a less than one degree and otherwise has a degree of more than one. In these three cases, the return to scale is constant, increasing, and decreasing respectively. This condition mathematically is understandable from relation (3).

The degree one homogeneity condition in Mughasatah function is quite meaningful; therefore, according to Euler theorem of the income distribution ${ }^{8}$, we can use this condition to divide the yields of Mughasatah contract between depositors and entrepreneur. In other words, in homogeneity condition, if all factors of production increase/decrease proportionally, production will also increase/decrease proportionally. In this case, since the average productivities of factors of production are unchanged, production productivity will not change. Euler theorem explains that in a homogeneous function of degree $\mathrm{j}$, the following relation exists:

$$
L \cdot f_{L}+(K+B) \cdot f_{K+B}=j \cdot f(K+B, L)
$$

Where, $f_{\mathrm{L}}$ and $\mathrm{f}_{\mathrm{K}+\mathrm{B}}$ are marginal productivities of labor (work of entrepreneur) and capital (deposit + paid in capital) respectively. By replacing (1) in relation (4), with the assumption of homogeneity of degree one $(\mathrm{j}=1)$, we obtain the following relation:

$$
L \cdot f_{L}+(K+B) \cdot f_{K+B}=Q
$$

By this theorem, we can understand that total value of Mughasatah is equal to the sum of multiplication of marginal productivities of labor $\left(\mathrm{f}_{\mathrm{L}}\right)$ by $\mathrm{L}$ and multiplication of marginal productivity of total capital of depositor and entrepreneur $\left(\mathrm{f}_{\mathrm{K}+\mathrm{B}}\right)$ by total capital of moghsit and ghasit $(\mathrm{K}+\mathrm{B})$. In other words, if we want to divide the result of Mughasatah based on marginal productivities of labor work of entrepreneur and his contributed capital plus the capital of depositor, the total value of Mughasatah are distributed. Euler theorem has a basic role in marginal productivity theory of distribution, and accordingly, each part of the Mughasatah will receive his share from the results of Mughasatah. It should be mentioned that homogeneity of degree one causes the profit function of

${ }^{6}$ - This is the intersection point of marginal and average production curves.

7 - There are many production functions with different economic and mathematical characteristics. See: Eatwell, J, M. \& Milgate, P. Newman (1988). The new Palgrave dictionary of economics. MacMillan.

Savabi Asl, Farhad; Bidabad, Bijan and Shahrestani, H., (1993). Estimating Aggregate Investment Function of Iran, Considering Various Functions, MS. Dissertation, Islamic Azad University, Tehran.

${ }^{8}$ See: George J. Stigler (1946), Production and Distribution Theories: The Formative Period, New York, Mac Millan. 
Mughasatah to be also homogeneous of degree one. In other words, if we consider $\pi$ as Mughasatah profit, we will have:

$$
t . \pi=f(t(K+B), t L)-t(K+B)-t L
$$

That is to say, if the labor-work of entrepreneur and the capital of depositor plus the contributed capital of entrepreneur increase proportionally (by t), Mughasatah profit will also increase proportionally (by t). By applying above analysis, we can distribute the profits of each part of Mughasatah based on productivity ratio of capital (including the capital of depositor and the contributed capital of entrepreneur) and labor work of entrepreneur from the value added of Mughasatah activity according to the following formula. In the following formula, the capital value means the deposit of depositor; contributed capital is the total fund and asset (cash and noncash) brought by the entrepreneur into the project; and value added is the total profit or value-added obtained by the work of entrepreneur, through financial participation; and total value added is the value created by using all factors of production in Mughasatah activity, and the project value is the assessed (valuated) value of Mughasatah project. In other words, we have:

$\mathrm{K}+\mathrm{B}+\mathrm{L}=\mathrm{Q}=\mathrm{C}+\mathrm{V}$

which means that sum of value added (V) and cost (C) is equal to Mughasatah value (Q) and is equal to the total value of labor work (L) and deposit (K) and contributed capital (B). This is because:

$\pi=\mathrm{V}$

That is value added is equal to the profit of Mughasatah activity. Moreover, the assessed value of the project is equal to the total value added plus cost:

$\mathrm{C}+\mathrm{V}=\mathrm{Q}$

Accordingly, the value added emanated by the labor work of entrepreneur in Mughasatah will be equal to the assessed value of the project minus the value of deposit minus contributed capital of the entrepreneur:

$$
\mathrm{L}=\mathrm{Q}-\mathrm{K}-\mathrm{B}
$$

Therefore, the profit share ratios of moghsit from the created value added $\left(\mathrm{R}_{\mathrm{K}}\right)$ plus profit share ratio of ghasit from the value added $\left(\mathrm{R}_{\mathrm{B}}\right)$ will be equal to the ratio of the value of moghsit capital, plus the contributed capital of ghasit to the total value of project $(\mathrm{Q})$; and also, the profit share ratio of ghasit emanated from his labor work in the created value-added will be equal to the ratio of assessed value added of the project to the total value of project. In other words:

$$
\begin{aligned}
& R_{K}+R_{B}=(K+B) / Q \\
& R_{L}=V / Q
\end{aligned}
$$

The profit shares of moghsit and ghasit are calculated by multiplying their profit share ratios by the assessed value added of the project. Or:

$$
\begin{aligned}
& \pi_{K}=R_{K} \times V \\
& \pi_{B}=R_{B} \times V
\end{aligned}
$$




$$
\pi_{L}=R_{L} \times V
$$

Accordingly, each part of the Mughasatah (moghsit and ghasit) will share the created value added based on their productivity ratios. In other words, if we add up the above relations, we will reach the following relation in which the value added is equal to the labor work yield, plus capital yield, plus the value added of contributed capital:

$$
\pi_{K}+\pi_{B}+\pi_{L}=V
$$

This distribution is in accordance with Euler theorem of marginal income distribution into capital and labor in which each party (labor work, deposit, and contributed capital) receives according to his productivity. Therefore, the amount of ownership of moghsit in principal and profit will be:

$$
P_{K}=\pi_{K}+K
$$

which means that the dividend of moghsit $\left(\mathrm{P}_{\mathrm{K}}\right)$ at the time of assessing the project (at the end of construction period) is equal to the moghsit's capital value (deposit) and his profit. The dividends of ghasit $\left(\mathrm{P}_{\mathrm{L}}\right)$ at the end of the construction period will be equal to the total profit of ghasit plus the value of his contributed capital:

$$
P_{L}=\pi_{L}+B
$$

Adding these two relations show that after the end of the construction period, the dividend of ghasit plus the dividend of moghsit is equal to the total value of deposit plus contributed capital of the entrepreneur, plus profits of ghasit and moghsit:

$$
P_{K}+P_{L}=\pi_{K}+\pi_{L}+K+B
$$

In other words, the total payments to ghasit and moghsit are equal to total deposit and contributed capital of entrepreneur and Mughasatah profit:

$$
P_{K}+P_{L}=\pi+K+B
$$

\section{Accounting Procedure for Apportionment}

In simpler words, ratios of the dividends of each part of the project from the value added of the Mughasatah activity at the end of construction period is calculated on the basis of the yield of capital (deposit) and contributed capital (of entrepreneur) and labor work (of entrepreneur) on the basis of following formulas. In following relations, capital value is the amount of depositor's deposit and contributed capital is the contribution of entrepreneur and labor value is the labor work of entrepreneur resulted from his activity. On the other hand, value-added is the produced value in excess of the original capital of depositor plus the contributed capital of the entrepreneur, which is cleared by assessing the project value. In other words, the market value of the project at the end of the construction period minus depositor's capital and contributed capital of the entrepreneur is the project value added at the end of the construction period.

Therefore, the markup cost of the project is equal to the capital value of depositor plus contributed capital of the entrepreneur:

$\mathrm{C}=\mathrm{K}+\mathrm{B}$

Value-added plus markup cost is equal to the value of labor work plus the value of the contributed capital plus value of the depositor's capital: 
$\mathrm{K}+\mathrm{B}+\mathrm{L}=\mathrm{C}+\mathrm{V}$

The assessed value of the project is equal to the value added plus markup production cost:

$\mathrm{C}+\mathrm{V}=\mathrm{Q}$

Alternatively, the assessed value of the project is equal to the value of labor work productivity, plus the value of paid-in capital plus depositor's capital (deposit) value:

$\mathrm{K}+\mathrm{B}+\mathrm{L}=\mathrm{Q}$

Accordingly, the yield of the depositor of the created value-added will be equal to the ratio of depositor capital to the assessed value of the project at the end of the construction period. The ratio of the yield of the entrepreneur from the project from the created value-added will be equal to the total of the ratios of his contribution (paid in capital and work) to the assessed (valuated) value added:

$\mathrm{R}_{\mathrm{K}}=\mathrm{K} / \mathrm{Q}$

$\mathrm{R}_{\mathrm{B}}=\mathrm{B} / \mathrm{Q}$

$\mathrm{R}_{\mathrm{L}}=\mathrm{V} / \mathrm{Q}$

The dividends of depositor and entrepreneur from value added are calculated by multiplying their yield ratios by project value added at the end of the construction period. In other words, the dividend of depositor from value added is equal to depositor yield ratio multiplied by created value added:

$\pi_{\mathrm{K}}=\mathrm{R}_{\mathrm{K}} \times \mathrm{V}$

Entrepreneur's contributed capital dividend from value added is equal to his contributed capital yield ratio multiplied by value added:

$\pi_{\mathrm{B}}=\mathrm{R}_{\mathrm{B}} \times \mathrm{V}$

Entrepreneur's labor work dividend from value added is equal to his labor work yield ratio multiplied by value added:

$\pi_{\mathrm{L}}=\mathrm{R}_{\mathrm{L}} \times \mathrm{V}$

In other words, depositor's dividend from value added is equal to his capital yield from value added. And Entrepreneur's contributed capital dividend from value added is equal to his paid in capital yield from value added. And Entrepreneur's labor work dividend from value added is equal to his labor work yield from value added.

The share of depositor from the assessed value of the project is calculated by adding his share from value-added and his deposit. The share of the entrepreneur from the assessed value of the project is calculated by adding up his contributed capital share from value-added and his labor work contribution from value-added, plus his contributed capital. In other words:

$\mathrm{P}_{\mathrm{K}}=\pi_{\mathrm{K}}+\mathrm{K}$

$\mathrm{P}_{\mathrm{B}+\mathrm{L}}=\pi_{\mathrm{B}}+\pi_{\mathrm{L}}+\mathrm{B}$

Sum of the last two relations shows that after distribution: The share of depositor from the project plus the share of 
entrepreneur from the project is equal to value added plus the deposit of the depositor plus entrepreneur's contributed capital.

$\mathrm{P}_{\mathrm{K}}+\mathrm{P}_{\mathrm{B}+\mathrm{L}}=\mathrm{V}+\mathrm{K}+\mathrm{B}$

If we add up the above relations, we reach to the following relation in which: depositor's capital yield + entrepreneur's capital yield + entrepreneur's labor yield is equal to the value added of Mughasatah. This economically is adapted to Euler income distribution of value added to labor and capital according to their productivity (yield).

\section{Calculation of Mughasatah Installment in Finitude Projects}

"Mughasatah Certificate" is issued for finitude projects through Mughasatah contract. In this process, depositor provides funds, and entrepreneur mixes it with his own contributed capital and executes the project. At the end of the construction period, the bank assesses the project and based on duration and amortization date of depositor's sources, the installment method to pay depositor back is defined. In this case, the calculation of installments includes two parts. One is the installments for paying back the principal capital of depositor, and the other is the return or yield of his capital.

Parameters used to calculate the installments for finitude projects contracts are the amount of deposit (K), the entrepreneur's contributed capital (B), construction period (M), and operational life of the project after construction (T).

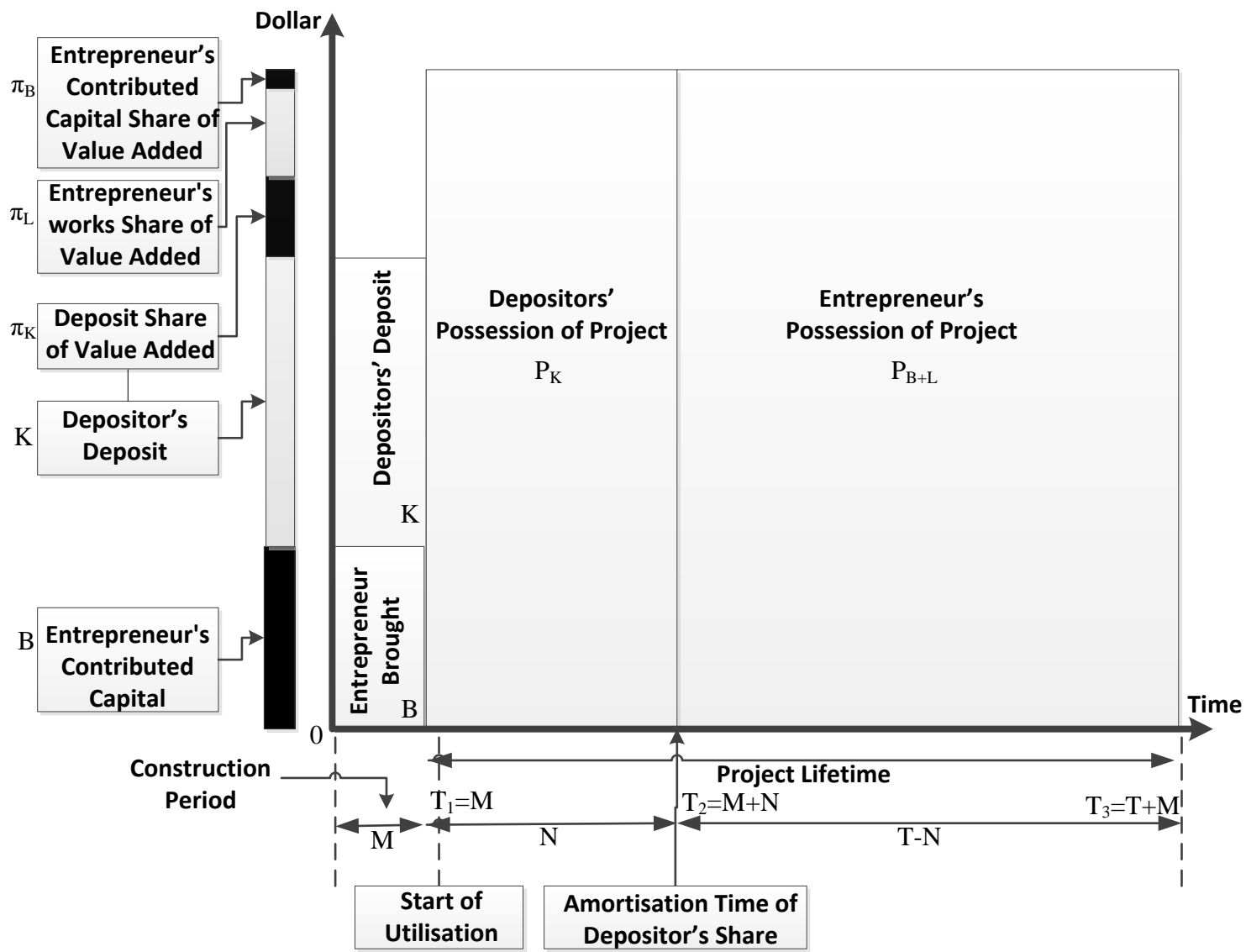

Figure 1.

Considering figure 1, the entrepreneur, together with his contributed capital (B), receives the deposit of depositor 
(K) at the beginning of the construction period and starts construction according to the contract. The construction period is $\mathrm{M}$. At the end of the construction period, and the start of the utilization of the project; bank assesses (valuate) the value of the project $(\mathrm{Q})$ at market price. If the project were sold at this time, the shares of depositor and entrepreneur would be calculated by the following relations:

$\mathrm{P}_{\mathrm{K}}=\pi_{\mathrm{K}}+\mathrm{K}$

$\mathrm{P}_{\mathrm{B}+\mathrm{L}}=\pi_{\mathrm{B}}+\pi_{\mathrm{L}}+\mathrm{B}$

That is the claims of depositors and entrepreneur from the project are obtained by the above relations. Now, the entrepreneur buys the share of the depositor in installment and becomes the owner of parts of the project gradually, and finally by paying back all installments, becomes the owner of the whole project. Now suppose that the useful lifetime of the project from the beginning of exploitation is $\mathrm{T}$ periods (years). If we want to show the shares of depositor and entrepreneur through the figure 1 , it means that from time $T_{1}=M$ to $T_{2}=M+N$ the ownership belongs to depositors and from $\mathrm{T}_{2}=\mathrm{M}+\mathrm{N}$ to $\mathrm{T}_{3}=\mathrm{T}+\mathrm{M}$ the entrepreneur will be the owner of the project. $\mathrm{T}_{2}$ is the time that participation concludes. If the entrepreneur pays back the share of depositor until $\mathrm{T}_{2}$, he will gain the total ownership from $\mathrm{T}_{2}$ to $\mathrm{T}_{3}$.

Now suppose the entrepreneur obtains the possession of the project from time $\mathrm{T}_{1}=\mathrm{M}$ and pays back depositor's share by installment. In this case, we need to calculate the amount of his installments. Here, we should consider a few issues. First, when the final date of amortization of depositor's share is? Second, what the preferential rate or capital time-yield of depositor's deposit (which is in possession of the entrepreneur) is?

To calculate the amortization period $(\mathrm{N})$, we use the following relation:

$\mathrm{N}=\frac{\mathrm{P}_{\mathrm{K}}}{\mathrm{P}_{\mathrm{K}}+\mathrm{P}_{\mathrm{B}+\mathrm{L}}} \cdot \mathrm{T}$

To obtain the time-yield rate (r) of depositor's deposit, we use the ratio of the total yield of the project which is equal to the value added (V) of the project to total capital resources used (deposit and contributed capital of entrepreneur). The time-yield rate of the project at the beginning and during the construction period is indefinite and will be assessed afterward at the end of construction period by assessing the value of the project; and therefore, it is not Riba (usury) to be prefixed at the beginning. That is:

$\mathrm{r}=\pi_{\mathrm{K}} /(\mathrm{K} \times \mathrm{M})$

And $\mathrm{r}$ is the time-yield rate of depositor's deposit. Considering the fact that the construction period might be longer than one period (year), inserting $M$ in the denominator, will estimate the time-yield rate of capital for each period (such as a year). This return rate ( $r$ ) is calculated only for the deposit of depositor that is obtained practically in the process of construction, and it is not interest rate and is capital return rate. This rate suggests that if depositor and entrepreneur wanted to invest in a similar project by using depositor's deposits, the entrepreneur should pay depositor at a capital rate of return (r). Therefore, the capital yield rate of the depositor in the next periods will be calculated by this rate of return (r).

If the entrepreneur had to pay back all the share of the depositor at time $T_{2}$, he should pay the amount of $\mathrm{P}_{\mathrm{K}}(1+\mathrm{N} \times \mathrm{r})$. If the entrepreneur wants to pay back depositor's principal and profit by equal installments, his monthly payments would be equal to:

$\mathrm{I}_{\mathrm{t}}=\mathrm{P}_{\mathrm{K}}(1+0.5 \times \mathrm{N} \times \mathrm{r}) / \mathrm{N} \quad \mathrm{t}=1, \ldots, \mathrm{N}$

In which, $t$ shows periods of 1 to $\mathrm{N}$. It is clear that:

$\sum_{\mathrm{i}=1}^{\mathrm{N}} I_{t}=\mathrm{P}_{K}(1+0.5 \times \mathrm{N} \times \mathrm{r})$ 
The 0.5 multiplier in the above relations is because the installment payment starts from the beginning.

Entrepreneur and depositors can unambiguously agree to change the schedule of the installment from equal payments via the bank.

\section{Calculation of Rental Mughasatah Installment in Finitude Projects}

"Rental Mughasatah Certificate" is issued for finitude projects by Rental Mughasatah contract. In this process, depositor provides funds for the entrepreneur, and he mixes depositor's deposit with his own contributed capital and carries out the project. Bank assesses the project at the end of the construction period and according to the preliminary agreement; the project will be in possession of the entrepreneur as a rented property until the amortization date of depositor's share. According to the assessed value of the project and the amortization date, the bank calculates the amount of rent and installment. Bank (on behalf of the depositor) and entrepreneur will agree upon the rent. The defined installment consists of two parts: one for the principal deposit, and other for the periodic rent which entrepreneur should pay to the depositor. The difference between Mughasatah and Rental Mughasatah is fixing the rent from the beginning in Rental Mughasatah.

Effective parameters in calculations of Rental Mughasatah are the amount of deposit of depositors (K), contributed capital of entrepreneur (B), construction period (M), and operating lifetime of the project after construction (T), the agreed rent according to the signed contract $(\mathrm{S})$.

Consider the previous diagram in figure 1. The entrepreneur, with his own contributed capital (B) and deposits of depositors (K), starts the construction of the project. Construction takes M periods. At the end of construction, when the project becomes operational, the bank assesses (valuates), the market value of the project $(\mathrm{Q})$. As in the previous case, if the project were to sell, the share of entrepreneur and depositor would be as (34) and (35) which means their claims at the end of construction period would be defined according to these relations. Now, the entrepreneur buys depositor's share by installments, and by paying each installment, his own share increases until he becomes the owner of the total project. During this period, in addition to paying installment for the principal, the entrepreneur has to pay rent to depositors according to the pre-agreed contract. The forecasted operating lifetime of the project after the construction period is (T) (e.g., years). If we want to show time ownership of depositor and entrepreneur in the graph, it means that from time $\mathrm{T}_{1}=\mathrm{M}$ until $\mathrm{T}_{2}=\mathrm{M}+\mathrm{N}$, ownership belongs to depositors, and from time $\mathrm{T}_{2}=\mathrm{M}+\mathrm{N}$ until $\mathrm{T}_{3}=\mathrm{T}+\mathrm{M}$, the entrepreneur will be the owner. $\mathrm{T}_{2}$ is the expiration date of the contract with the depositor. If the entrepreneur pays back depositor's shares at this time, he will become the owner of the project from then after.

Now consider a case in which the entrepreneur takes possession of the project from the beginning and starts to pay back the principal capital of depositor and its rent for using the property. Then, we have to calculate his installment and rent. First, we have to define $T_{2}$, which is the amortization date for depositor's claim. To obtain amortization date $(\mathrm{N})$, we use the previous relation of (36) which means that the entrepreneur should pay back depositor's claim on the assessed value of the project in $\mathrm{N}$ periods (years). Since the value of the project is not defined at the beginning of the project and can be assessed at the end of construction date of the project, the share of depositors cannot be calculated at the beginning.

If they had agreed to pay back the share of the depositor at time $T_{2}$, he had to pay $\mathrm{P}_{\mathrm{K}}$. Since he wants to pay this amount in $\mathrm{N}$ equal installments, his periodic installment will be $\mathrm{P}_{\mathrm{K}} / \mathrm{N}$. His installment plus his rent is extracted as in the following relation:

$\mathrm{I}_{\mathrm{t}}=\mathrm{S}_{\mathrm{t}}+\mathrm{P}_{\mathrm{K}} / \mathrm{N} \quad \mathrm{t}=1, \ldots, \mathrm{N}$

In which, $S_{t}$ is the amount of rent for periods of $t=1, \ldots, N$. Rent installments can be unequal for all these periods according to the agreed contract.

The total amount of payment to depositors for principal and rent will be equal to:

$$
\sum_{\mathrm{i}=1}^{\mathrm{N}} I_{t}=\mathrm{P}_{K}+\sum_{\mathrm{i}=1}^{\mathrm{N}} S_{t}
$$

By the agreement of entrepreneur and bank on behalf of the depositor, $\mathrm{N}$ can be defined without using the above 
method. Rent can be defined as a percent of the value of the project at the time of signing the contract. In other words, the entrepreneur and bank (on behalf of the depositor), can define the rent as a percent of the value of the project when it is constructed and becomes operational. In this case, periodic (annual) rent is calculated by the following relation:

$\mathrm{S}_{\mathrm{t}}=\mathrm{s} \times\left(\mathrm{P}_{\mathrm{K}} / \mathrm{N}\right)$

$\mathrm{S}_{\mathrm{t}}$ is periodic rent, and $\mathrm{s}$ is the ratio of the share of total rent from the assessed value of the project. "s" is a condition of the contract. In this case, rent has an exact legal justification for using the benefits of a rental property. Depositor leaves rental property to be in possession of the entrepreneur, and he is legally the one who has rented the object. The amount of rent can be variable, and this is not against Civil Law. It is necessary to mention that the assessed value of the project at the beginning of the project is unknown and will be determined (valuated) by the bank at the end of the construction period at market prices.

\section{Calculation of Rental Mughasatah Installment in Endless Projects}

If the project is endless, calculation of the shares of depositor and entrepreneur at the end of the construction period is the same as for finitude projects. Now, if the project is defined as an endless (productive) project in the contract, the depositor will also have a periodic share in the productivity of the project during the exploitation period plus periodic installment. In this case, the depositor is not just lessors, but he participates in the profit and loss of the project.

"Musharakah Mughasatah Certificate" is issued for the endless project through "Musharakah Mughasatah" contract. In this process, depositor provides fund and entrepreneur mixes it with his own resources and starts constructing the project. At the end of the construction period, the bank assesses the project and according to the amortization, period duration calculates the installments and adds it to depositor's share from the value added for every period according to entrepreneur's financial reports. According to the signed contract, the project will be monitored by the bank's trustee until depositor's claim is amortized. In addition, in this case, payments to the depositor by entrepreneur consist of two parts: installment concerning the return of the principal deposit of depositor, and his share from periodic value added of the project. The difference between "Musharakah Mughasatah" and the previous case of "Rental Mughasatah", is that in "Musharakah Mughasatah", periodic value added is calculated and depositor's share is added to the assessed depositor's share value of the project.

Effective parameters used in fixing contract and calculations are the amount of depositor's deposit (K), contributed capital of entrepreneur (B), construction period (M), and operational lifetime of the project after construction period (T).

In this case, the amount of installment for the principal deposit of depositor is similar to the case of the finitude project contract. The amortization period for depositor's share is similarly obtained as in the previous case by (36). To calculate the amount of each installment, if the entrepreneur had to pay back the whole share of the depositor at the time $\mathrm{T}_{2}$, he had to pay the amount of $\mathrm{P}_{\mathrm{K}}$. In this case, the amount of periodic installment for the assessed value of the project $\left(\mathrm{P}_{\mathrm{K}}\right)$ will be $\mathrm{P}_{\mathrm{K}} / \mathrm{N}$. The productivity of the project is as the share of depositor from the value added by the project from the end of construction period $\mathrm{T}_{1}=\mathrm{M}$ up to the date of amortization of depositors' claim $\mathrm{T}_{2}=\mathrm{M}+\mathrm{N}$ which should be paid him annually. The total share of depositor from his principal deposit plus the assessed value of the project and his value added (due to project productivity) share will be paid by the entrepreneur. At every time period $(\mathrm{t}=1, \ldots, \mathrm{N})$, depositor receives his value-added share in that period $\left(\mathrm{V}_{\mathrm{t}}^{\mathrm{K}}\right)$ in addition to the installment for his principal deposit plus his share from the assessed value of the project. Therefore, the total amount of year on year installment will be:

$I_{t}=V_{t}^{K}+P_{K} / N \quad t=1, \ldots, N$

In which, $\mathrm{t}$ shows the periods from 1 to $\mathrm{N}$. It is clear that:

$\sum_{\mathrm{i}=1}^{\mathrm{N}} I_{t}=P_{K}+\sum_{\mathrm{i}=1}^{\mathrm{N}} V_{t}^{K}$

Keeping in mind that capital time-yield rate for the deposit (r) is not considered for endless projects. But instead, the 
entrepreneur has to pay his periodic share value added up to the end of the amortization period.

If we name the periodic value added of the project for periods of $\mathrm{t}=1, \ldots, \mathrm{N}$ as $\mathrm{Vt}$ which can be positive, negative, or zero, it should be divided proportionally according to the shares of depositors and entrepreneur. The dividend is paid to "Musharakah Mughasatah Certificate" holder at the end of each period. Therefore, at the end of each financial period and calculating profit and loss, the share of "Musharakah Mughasatah Certificate" holder from the project yield $\left(\mathrm{V}_{\mathrm{t}}^{\mathrm{K}}\right)$ will be calculated and plus the installment for principal deposit will be calculated by entrepreneur and paid to certificate holder via bank. Arithmetically we have:

$\mathrm{V}_{\mathrm{t}}^{\mathrm{K}}=\frac{\mathrm{P}_{K}}{P_{K}+P_{B+L}} \cdot V_{t}$

Considering the above explanation, total shares of depositor for his installment and periodic value added will be equal to $\mathrm{V}_{\mathrm{t}}^{\mathrm{K}}+\mathrm{P}_{\mathrm{K}} / \mathrm{N}$. $\mathrm{P}_{\mathrm{K}} / \mathrm{N}$ is depositor's share for his capital contribution from the assessed value of the project, and $\mathrm{V}_{\mathrm{t}} \mathrm{K}$ is his share from the periodic value added of the project which will be paid to the depositor ("Musharakah Mughasatah Certificate" holders).

\section{Considerations for Installment Financial Sharing (IFS)}

Since in Mughasatah, the deposit of depositor and contributed capital of entrepreneur mix together, they have mutual rights. The entrepreneur can insure the share of the depositor to cover the probable risk. If the assessed value of the project was less than its cost, it is possible to use "loss insurance" to cover the probable loss. Therefore, the entrepreneur insures depositor's loss. This insurance is obligatory for all three kinds of Mughasatah (Mughasatah, Rental Mughasatah, and Musharakah Mughasatah). In this case, according to the signed contract, the project will be sold by auction under the supervision of the bank's trustee, and the contract will be settled, and the bank receives no commission. This process is only applicable in "Mughasatah" and is not applicable in Rental Mughasatah and Musharakah Mughasatah.

Installment Financial Sharing (IFS) operational mechanism ${ }^{9}$, organization ${ }^{10}$, and instructions comply with Rastin PLS banking instructions. These instructions include:

- Checking capability of the entrepreneur

- Guarantees, collaterals and paid in capital

- Providing economic, technical and financial justification proposal

- Documents and evidence necessary for project evaluation

- Bank yields

- Supervision standards and regulations

- Entrepreneur reporting

- Accounting and auditing

- Timing and cost changing

- Inflation effects on income, cost and net outcome of the project

- Failure because of entrepreneur's delay and timing change

- New sharing (capitalization during the operation)

- Settlement with entrepreneur

- Arbitration

- Force majeure

- Compilation of PLS banking contracts

- General conditions of PLS contracts

- Trustee competency

- Depositor dispensing and immature settlement

- Replacing Pazireh Certificates with shares in (productive) endless projects

\footnotetext{
${ }^{9}$ Bidabad, Bijan, M. Allahyarifard, The Executive Mechanism of Profit and Loss Sharing (PLS) Banking. http://www.bidabad.com/doc/PLS-banking-Executive-Mechanism.pdf

${ }^{10}$ Bidabad, Bijan, Nasaji Safarzadeh Masoud, Aghabeigi, Jina, Organization of Profit and Loss Sharing (PLS) Banking in Bank Melli Iran. Planning and Research Department of Bank Melli Iran, Tehran, 2010. http://www.bidabad.com/doc/PLSorganization.pdf
} 
- Insurance coverage

- Certificates transaction

- Future certificate issuance

- Future certificate purchase and sale order

- Types of guarantees and collaterals for the goodness of carrying activities and playing commitments in compliance with general PLS instruction

- Banks receipts

- Commodity checking and control

- Raw material and final goods standards

- Delivering final goods and termination

- Insurance instruction in Joalah Financial Sharing (JFS)

- Delay in payment and abstaining from fulfilling obligations

- Entrepreneur's company corporate governance

- Professional behavior of trustee and appraiser

- Entrepreneur's company information disclosure

\section{Conclusion}

Real establishment of usury-free Islamic banking can remove many world economic problems such as crises ${ }^{11}$. To reach this goal, Rastin Banking with Islamic and ethic essence was designed and developed. Rastin Banking should be developed to fulfill the needs of clients and to become a good substitute for conventional banking. In this regards, Installment Financial Sharing (IFS) was designed. IFS is a fully new financial innovation and works under Rastin PLS Banking. It provides the background for depositor participation in the investment project in which entrepreneur desires to preserve his own ownership, and depositor wishes to obtain periodic income (monthly, seasonal, or yearly). These two needs are important desires of banks clients in both realms of borrowing and lending. IFS fill this gap in profit and loss sharing mechanism.

\section{References}

Bidabad, Bijan. (2014). New Operational Islamic Banking System, Volume One, Theoretical Foundations, LAP Lambert Academic Publishing, OmniScriptum GmbH \& Co. KG, ISBN: 978-3-659-54463-7.

Bidabad, Bijan. (2014). New Operational Islamic Banking System, Volume Two, Applicational Issues, LAP Lambert Academic Publishing, OmniScriptum GmbH \& Co. KG, ISBN: 978-3-659-55210-6.

Bidabad, Bijan. Installment Financial Sharing (IFS), a subsystem of Rastin PLS banking, Planning and Research Department of Bank Melli Iran, Tehran, 2011. http://www.bidabad.com/doc/detailed-ifs.pdf

Bidabad, Bijan, Fluctuations and Business Cycles Prevention by New Financial Instruments and Banking Structure Reform

http://www.bidabad.com/doc/Fluctuations-and-Cycles.pdf

Bidabad, Bijan, Stabilising Business Cycles by PLS Banking and Ethic Economics. http://www.bidabad.com/doc/pls-business-cycles-en.pdf

Bidabad, Bijan, M. Allahyarifard, The Executive Mechanism of Profit and Loss Sharing (PLS) Banking. http://www.bidabad.com/doc/PLS-banking-Executive-Mechanism.pdf

Bidabad, Bijan (2018), General Regulatory Framework in Rastin Profit and Loss Sharing Banking (Part IOperational Context). Journal of Business and Finance in Emerging Markets, JBFEM, [S.1.], v. 1, n. 1, p. 1126, May. ISSN 2580-5568. https://doi.org/10.32770/jbfem.vol111-26

http://www.bidabad.com/doc/rastin-regulatory-en-I.pdf

\footnotetext{
11 - Bidabad, Bijan, Fluctuations and Business Cycles Prevention by New Financial Instruments and Banking Structure Reform http://www.bidabad.com/doc/Fluctuations-and-Cycles.pdf

Bidabad, Bijan, Stabilizing Business Cycles by PLS Banking and Ethic Economics. http://www.bidabad.com/doc/pls-businesscycles-en.pdf
} 
Bidabad, Bijan (2018), General Regulatory Framework in Rastin Profit and Loss Sharing Banking (Part II-Legal Groundwork). Journal of Business and Finance in Emerging Markets, JBFEM, JBFEM, [S.1.], v. 1, n. 2, p. 109-126, Nov. ISSN 2580-5568.

https://doi.org/10.32770/jbfem.vol1109-126

http://www.bidabad.com/doc/rastin-regulatory-en-II.pdf

Bidabad, Bijan (2019), General Regulatory Framework in Rastin Profit and Loss Sharing Banking (Part IIIAuxiliary Provisions). Journal of Business and Finance in Emerging Markets, JBFEM, May, Vol 2, No. 1, pp. 51-65. ISSN 2580-5568.

https://doi.org/10.32770/jbfem.vol251-66

http://www.bidabad.com/doc/rastin-regulatory-en-III.pdf

Bidabad, Bijan, Nasaji Safarzadeh Masoud, Aghabeigi, Jina, Organization of Profit and Loss Sharing (PLS) Banking in Bank Melli Iran. Planning and Research Department of Bank Melli Iran, Tehran, 2010.

http://www.bidabad.com/doc/PLS-organization.pdf

Bidabad, Bijan, Safaeipour, Mohammad, The Electronic Market for Transaction of Musharakah (Partnership)/Pazireh (Subscripted) Certificates. Fifth Conference of E-Commerce, 23-24, November 2008, Ministry of Commerce, Tehran, Iran.

http://www.bidabad.com/doc/charchoobe-bazare-electronic-pls.pdf

Eatwell, J., M. Milgate, P. Newman (1988). The new Palgrave dictionary of economics. MacMillan.

George J. Stigler (1946), Production and Distribution Theories: The Formative Period, New York, Macmillan.

Henderson, R., Quandt, P. (1982), Microeconomic theory, a mathematical approach. Mc-Graw Hill.

Savabi Asl, Farhad; Bidabad, Bijan and Shahrestani, H., (1993). Estimating Aggregate Investment Function of Iran, Considering Various Functions, MS. Dissertation, Islamic Azad University, Tehran.

\section{Copyrights}

Copyright for this article is retained by the author(s), with first publication rights granted to the journal.

This is an open-access article distributed under the terms and conditions of the Creative Commons Attribution license (http://creativecommons.org/licenses/by/4.0/) 